\title{
Alexandre Dumas, La Dame de Montsoreau
}

\section{Lise Sabourin}

\section{OpenEdition}

\section{Journals}

Édition électronique

URL : https://journals.openedition.org/studifrancesi/6348

DOI : 10.4000/studifrancesi.6348

ISSN : 2427-5856

Éditeur

Rosenberg \& Sellier

\section{Édition imprimée}

Date de publication : 1 novembre 2010

Pagination : 567

ISSN : 0039-2944

\section{Référence électronique}

Lise Sabourin, «Alexandre Dumas, La Dame de Montsoreau », Studi Francesi [En ligne], 162 (LIV | III) |

2010, mis en ligne le 30 novembre 2015, consulté le 21 septembre 2021. URL : http://

journals.openedition.org/studifrancesi/6348; DOI : https://doi.org/10.4000/studifrancesi.6348

Ce document a été généré automatiquement le 21 septembre 2021.

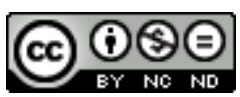

Studi Francesi è distribuita con Licenza Creative Commons Attribuzione - Non commerciale - Non opere derivate 4.0 Internazionale. 


\title{
Alexandre Dumas, La Dame de Montsoreau
}

\author{
Lise Sabourin
}

\section{RÉFÉRENCE}

ALEXANDRE DUMAS, La Dame de Montsoreau, édition présentée, établie et annotée par Janine GARRISSON, Gallimard, «Folio classique», 2008, pp. 1031.

1 Dans le grand élan de réédtions des romans dumasiens sensible depuis une dizaine d'années, la collection Folio classique de Gallimard met à la portée d'un large public le deuxième roman de la trilogie sur la Renaissance française d'Alexandre Dumas, dans une édition annotée par Janine Garrisson (pp.999-1023, après une chronologie de l'auteur et des vues du plan Truschet et Hoyau de Paris en 1552).

2 Elle souligne dans sa préface (pp. 7-27) le rythme soutenu qu'a dû suivre, jour après jour, pressé par l'intransigeant Véron, pour le feuilleton du «Constitutionnel», le romancier, aidé dans sa tâche par Maquet pour les informations historiques, des ébauches de scènes et des idées de péripéties. Mais, malgré l'urgence, le style dumasien continue à sublimer l'histoire de France d'une manière fort plaisante. La préfacière rétablit les réalités historiques: Charles IX était bien jeune à la mort de François II, il laisse sa régente de mère tenter de réconcilier les Français par le traité de SaintGermain en 1570, qui reconnaît aux calvinistes la liberté de conscience, une certaine liberté de culte, le droit d'accès à toutes fonctions et le refuge de trois villes en cas de troubles et massacres. Mais le mariage d'Henri de Navarre et Marguerite de Valois mécontente les catholiques ligueurs, et le massacre de la saint Barthélémy s'étend sans peine dans une capitale d'autant plus disposée à écouter les conseils d'intolérance que les protestants sont souvent des artisans prospères bons à piller; en fait, la nuit deviendra semaine de "vêpres parisiennes», puis saison sanglante en province. Henri III, roi plus intelligent et soucieux du bien commun qu'on ne l'a souvent 
présenté, vu ses moeurs et sa piété superstitieuse qui l'ont dévalorisé, tentera vainement l'accalmie.

Dumas, nourri des chroniques consignant au quotidien les événements de Pierre de l'Estoile, s'intéresse fort à ce monarque complexe, le muant peu à peu en personnage romantique incapable de s'opposer au destin dans une tragique solitude. Chicot, son bouffon, lui aussi inspiré d'un Gascon authentique, qui fit ses armes d'amuseur dans la ville de Loches et devint d'abord titulaire de l'enviée fonction (puisque touchant à la personne royale) de «porte-manteau du roi», en incarne la face réflexive par l'effet de miroir que ses libres plaisanteries lui permettent, le hissant subrepticement à un statut de conseiller. À ce roi lucide Dumas oppose son ombre noire, le dernier frère valois au visage buriné de petite vérole, où la tradition dès le $\mathrm{xvI}^{\mathrm{e}}$ siècle voyait le signe de ses turpitudes morales bien réelles. C'est pourquoi sa victime, dans cet amour triangulaire à la Hernani autour de Diane de Montsoreau, mariée à un vieux brutal et désirée par ce duc d'Anjou haïssable, est d'autant plus magnifiée: Louis de Clermont, sire de Bussy, fut effectivement beau, courageux, chevaleresque, admiré. L'Estoile est pourtant moins romanesque que Dumas sur ses relations avec la Dame de Montsoreau.

4 Ce roman, peut-être moins renommé que La Reine Margot et moins savoureux que Les Quarante-cinq, est cependant très brillant par son évocation d'un Paris de ruelles sombres et enchevêtrées, où gronde soudain une foule levée en émeutes comparables à celles des Trois Glorieuses ou de la future révolution de 1848. Il ajoute donc à l'intelligence d'une époque ancienne une vraisemblance perçue par les contemporains, tout en leur donnant à rêver sur une histoire d'amour éperdu. 